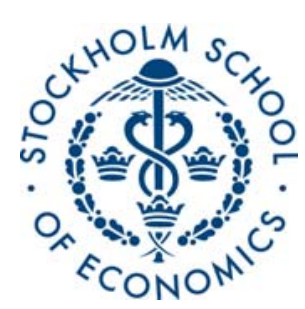

\title{
POLITICAL PARTICIPATION AND ENTREPRENEURIAL INITIAL PUBLIC OFFERINGS IN CHINA
}

\author{
Xunan Feng \\ Shanghai Jiaotong University \\ Anders C. Johansson \\ Stockholm School of Economics \\ Harvard University \\ Tianyu Zhang \\ The Chinese University of Hong Kong
}

\section{CERC Working Paper 17}

March 2011

Postal address: P.O. Box 6501, S-113 83 Stockholm, Sweden.

Office address: Holländargatan 30 Telephone: +46 87369360 Telefax: +46 8313017

E-mail: japan@hhs.se Internet: http://www.hhs.se/cerc 


\title{
Political Participation and Entrepreneurial Initial Public Offerings in China
}

\author{
Xunan Feng \\ Shanghai Jiaotong University \\ Anders C. Johansson* \\ Stockholm School of Economics \\ Harvard University \\ Tianyu Zhang \\ The Chinese University of Hong Kong
}

March 2011

\footnotetext{
${ }^{*}$ Corresponding author, Stockholm School of Economics, P.O. Box 6501, SE-113 83 Stockholm, Sweden. Phone: +46-8-736-9367. Fax: +46-8-31-3017. Email: anders.johansson@hhs.se. We thank Bin Ke, Donghua Chen, Jin Liu, Yiming Wang, Songtao Xu, participants at the 2010 Annual Conference of China Accounting and Finance Review, China Young Economist Society 2010 Annual Conference and seminar participants at Peking University, Shantou University and Tongji University for helpful comments. Johansson acknowledges financial support from the Bank of Sweden Tercentenary Foundation (RJ) and the Swedish Foundation for International Cooperation in Research and Higher Education (STINT).
} 


\title{
Political Participation and Entrepreneurial Initial Public Offerings in China
}

\begin{abstract}
This paper examines the value of political participation by private entrepreneurs in China. Using a unique sample of all initial public offerings by entrepreneurial firms during 1994-2007 and political participation by the controlling entrepreneurs, we test the hypothesis that firms with entrepreneurs who participate in politics are able to exploit rent-seeking opportunities that normal firms do not have access to. We document that the long-run stock performance after the IPO of firms controlled by entrepreneurs who participate in politics is superior to that of common entrepreneurial firms. Our results also show that political participation has a significant positive effect on change in operating performance and a negative effect on first-day returns. Moreover, we find that economic development and local institutions are important for this value effect. The difference in performance is even larger in regions characterized by more abundant rent-seeking opportunities, indicating that the value effect of political participation likely originates from rent seeking. This finding is consistent with the hypothesis that political participation facilitates entrepreneurs' rent seeking.
\end{abstract}

JEL Classification: G30; G32; G34; P48

Keywords: Political participation; Entrepreneurial firms; Corporate governance; Initial public offerings; China 


\section{Introduction}

As the private sector has become the growth engine of China's economy, companies established and controlled by entrepreneurs are receiving increasing attention (Allen et al., 2005; Djankov et al., 2006; Li et al., 2006; Huang, 2008). However, while relationships between politicians and firms are a common theme in studies on China's state-controlled firms (e.g., Fan et al., 2007; Li et al., 2008; Calomiris et al., 2010), the effects of political participation on entrepreneurial firms have not been thoroughly researched. In this paper, we focus on how Chinese private entrepreneurs engage in politics and analyze whether their political participation results in benefits for their firms. We do this by focusing on the effects of political participation on long-term performance after initial public offerings (IPOs) and underpricing of IPOs for firms controlled by private entrepreneurs.

The reasons for and effects of political participation are not self evident. One potential motivation behind political participation is that it may facilitate rent seeking. Politicians have direct and significant impacts on firms through government decisions. These decisions may influence the expected future cash flow for firms through various channels, including preferential access to government subsidies, beneficial taxation schemes, reduced regulatory constraints, preferential access to government contracts, etc. Politicians may therefore use their influence over firms to achieve their political as well as private objectives and to reward their supporters (e.g., La Porta et al., 2002; Rajan and Zingales, 2003). In a seminal paper, Krueger (1974) argues that it is natural 
for firms to devote economic resources toward rent seeking in order to compete for favorable policy decisions. In a related study, Shleifer and Vishny (1994) develop a model of bargaining between politicians and managers in which bribes and subsidies to state-controlled firms emerge. As a consequence, politically connected firms will demonstrate superior performance. An alternative reason for entering into politics is to strengthen the social status rather than for economic benefit. That is, entrepreneurs may choose to participate in politics for the common good. Political participation due to this alternative reason does not result in superior performance. The effects of political participation thus need to be analyzed empirically.

Apart from studies that focus on the U.S., the literature on political connections and their implications for firms around the world is still relatively modest ${ }^{1}$. Fisman (2001) find that firms with ties to President Suharto experienced significant losses in value following announcements of Suharto’s deteriorating health. In a related study, Faccio and Parsley (2007) document how an unexpected death of a politician results in a negative effect on firms from his or her home town. Johnson and Mitton (2003) analyze how capital controls imposed by Malaysia’s Prime Minister Mahathir in 1998 benefitted firms with political ties. Similarly, Ferguson and Voth (2008) show how German firms that supported the Nazi movement in 1933 outperformed regular firms.

\footnotetext{
${ }^{1}$ A number of studies have analyzed how political connections play an important role for U.S. firms (e.g., Buchanan, 1980; Roberts, 1990; Kroszner and Stratmann, 1998; Jayachandran, 2006; Knight, 2006; Benmelech and Moskowitz, 2007; Goldman et al., 2009).
} 
Claessens et al. (2008) find that firms that provided campaign contributions in the Brazilian 1998 and 2002 elections experienced higher increases in stock returns compared to other firms. They also estimate the cost of this form of rent seeking to be at least $0.2 \%$ of GDP per year during the election cycles. Faccio (2006) documents that firms with political connections tend to be from countries with weaker legal systems and higher levels of corruption. Faccio et al. (2006) also provide evidence that firms with political connections are more likely to be bailed out by the government.

Besides the general influence political connections may have on firms, some recent studies have focused on the channels through which political connections and rent-seeking work. One such channel is that of preferential access to finance. Khwaja and Mian (2005) document how politically connected firms in Pakistan borrow twice as much as other firms and exhibit much higher default rates. Similarly, Charumilind et al. (2006) show how Thai firms with connections to politicians and banks had better access to long-term debt before the Asian financial crisis. Dinc (2005) find that political motivations affect actions taken by government-owned banks in a set of emerging countries by focusing on banks' behavior during elections.

In this paper we focus on Chinese entrepreneurial firms, which we define as firms controlled by either entrepreneurs or their families. We explore the issue of whether or not political participation has a significant effect on entrepreneurial firms in China. The general purpose of inviting entrepreneurs to participate in politics is for them to serve the common good. For example, political entrepreneurs can give voice to institutional problems that constrain the development of entrepreneurial business. 
However, entrepreneurs may also utilize opportunities gained from political participation for their private benefit through rent-seeking within or beyond the political network in which they act. We empirically test the association between political participation and post-IPO performance. Our findings show that political participation is positively associated with post-IPO performance in terms of both long-term stock returns and changes in accounting performance. This is consistent with the argument that political participation facilitates rent seeking for entrepreneurs’ private benefit.

We further analyze whether regional institutions affect the relationship between post-IPO performance and political participation. We find that the relationship between the two is even stronger in regions with weaker institutions, which cultivate more rentseeking opportunities. This finding further supports the argument that political participation facilitates rent-seeking by private entrepreneurs.

This paper contributes to the literature in several ways. First, we address the side effects of an institution designed for social goods. That is, political participation by entrepreneurs generates private benefits for firms under their control. This finding is in sharp contrast to those of Fan et al. (2007), who find that politically connected firms underperform non-connected firms. The empirical analysis in this paper focuses on entrepreneurial firms while Fan et al. (2007) mainly focus on state-owned enterprises (SOEs). Thus, the incentive of the ultimate controlling shareholder is different. Our results also corroborate those of Allen et al. (2005), who document that China's formal sector (i.e. state-controlled firms) underperforms the informal sector (i.e. entrepreneurial firms). Second, we show that institutions matter in disciplining rent seeking through 
political participation. This implies that the development of institutions will encourage economic development as well as strengthen the political system. Third, we identify a key political resource utilized by private entrepreneurs for rent seeking. This study documents the value of networking through participation in important political events.

The rest of the paper is organized as follows. The next section offers a brief introduction to the setting for private firms in China. Section 3 then introduces the data sample and discusses its descriptive statistics. Section 4 presents the empirical results on post-IPO stock price and accounting performance of entrepreneurial firms. Section 5 analyzes the effects of entrepreneurs' political participation on underpricing during IPOs. Section 6 considers the potential effects of differences in rent-seeking opportunities and their relation to political participation. Finally, Section 7 concludes the study.

\section{Institutional Background}

The private sector was not an important driver for economic growth during the initial phase of China's economic reforms (e.g., Dougherty et al., 2007). Instead, a dualtrack system allowed for the gradual introduction of market prices with incentives for employees in the state-owned sector, resulting in increased efficiency and productivity (Naughton, 2007). During this period, enterprises owned by local collectives constituted one of the major successes in the transition from planned to market economy in China during the 1980s and early 1990s (Naughton, 1994). These firms managed to survive and exhibit an unprecedented level of growth partly due to ambiguous property right 
arrangements at the time, which allowed such firms to seek at least some protection from state expropriation (e.g., Weitzman and Xu, 1994; Li, 1996; Che and Qian, 1998). In a business environment marked by unclear property rights, this arrangement diminished the "holdup" problem, i.e. entrepreneurs hesitating to make new investments. By sharing a portion of the profit with the state as exchange for protection, the entrepreneurial firms were able to generate high growth. This explains why most entrepreneurial firms registered under "red hats" or as township-village enterprises (Tsai 2007; Huang 2008).

Opposite to previous findings that proper legal institutions lead to higher economy growth (e.g., Demirgüç and Maksimovic, 1998; Beck and Levine, 2002), Allen et al. (2005) find that even though China's private sector has been subject to poor legal protection and inferior access to financing channels, it has expanded faster than other sectors in China. In 2005, there were close to 30 million registered private firms in the country, accounting for approximately 50\% of China's GDP (Tsai, 2007). Using data for a quarter of a million companies, Dougherty et al. (2007) document how the private sector increased in importance at the turn of the century. Private firms accounted for approximately $25 \%$ of total industrial production in 1998, and more than $50 \%$ five years later. The private sector has thus grown into a major component of the Chinese economy. In addition to private firms' importance in the Chinese economy, the property rights of entrepreneurial firms are better defined today. As an example, a large number of firms organized under red hats are disaffiliating themselves from state agents. However, private entrepreneurs seek other channels to protect their property rights 
given that legal protection is not yet sufficient. Political participation is one such potential channel. In general, the development of the private sector in China has taken place on an uneven playing field. Private entrepreneurs have been discriminated against not only socially, but also politically as different political movements have cracked down on the private sector on a regular basis during the early stages of reform ( $\mathrm{Li}$ et al., 2008). One solution for private entrepreneurs when it comes to handling such discriminatory practice has been to foster close relationships with politicians. One way to do this is through participation in local and national politics.

\section{Data and Research Design}

\subsection{Data}

Our sample consists of all the entrepreneurial firms that went public during 1994 to 2007. There was a total of over 1400 IPOs during this period. Of these, we identified 265 IPOs carried out by firms that we classify as controlled by private entrepreneurs or their families. Following La Porta et al. (1999), we require that an entrepreneur or his or her family control at least $10 \%$ of the firm's shares for it to be defined as an entrepreneurial firm. We manually collected the political participation record, described in detail later, of the ultimate controlling shareholder of the company. We also constructed institutional data of the region where the company is registered. In addition to these data, we use accounting and stock price data from the China Security Market and Accounting Research (CSMAR) database. 


\subsection{Measuring Private Entrepreneurs' Political Participation}

We use membership at the Congress of the Chinese Communist Party (CCCP), the National People's Congress (NPC), the Chinese People's Political Consultative Conference (CPPCC), or their provincial counterparts as a proxy for political participation. ${ }^{2}$ The CCCP is the highest body within the Communist Party of China (CCP) and is held once every five years. The NPC functions as the country's legislative body and is formally the highest organ of the state. However, Chen and Dickson (2010) argue that the different levels of the NPC are de facto controlled by the CCP since deputies above the county level are elected by deputies at lower levels, who are in turn elected by individual voters. Thus, taking part in the NPC indicates an acceptance by the party and a direct channel to political power for private entrepreneurs. The CPPCC is an advisory body that consists of members from different parties and organizations. In practice, the CPPCC is to a large extent controlled by the CCP as well. Previously, the CPPCC has mainly been used as a vehicle for the CCP to win over non-CCP constituencies and get them to support the party. However, there are clear signs that the CPPCC is becoming more systematically involved in CCP's policymaking process (Shambaugh, 2009). Similar to the NPC, members of the CPPCC and its sub branches are approved by CCP organizations. Chen and Dickson (2010) argue that private entrepreneurs' membership in the NPC and CPPCC can be seen as a result of the CCP's

\footnotetext{
${ }^{2}$ Research has shown that private entrepreneurs have shown considerable interest in joining these state entities (e.g., Wright, 2010).
} 
strategy to include capitalists in the political system. On the other hand, entrepreneurs' decision to join any of these political bodies is likely related to the fact it enables them to build and exploit their political networks. That is, membership in the CCCP, NPC, CPPCC, or any of their provincial branches is very likely to result in significant rentseeking opportunities for private entrepreneurs. To capture indirect political connections, we look at both the entrepreneur and his or her family members.

\subsection{Institutional Effect on the Value of Political Participation}

Empirical research has shown that variations in institutional quality help explain cross-country differences in income (Hall and Jones, 1999; Acemoglu et al., 2001). Related studies look at how the level of rent seeking is dependent on a country's type of institutions. Research has also shown how effective property rights and the rule of law make it more difficult for rent seeking. A common result in this literature is that corruption and rent seeking has a negative effect on economic performance (e.g., Baumol, 1990; Murphy et al., 1991, 1993; Mauro, 1995; Shleifer and Vishny, 1998). In general, rent-seeking opportunities seem to be related to economic development, markets and institutions. We therefore expand our analysis by including three variables that capture these dimensions to see how they influence the effect political participation has on entrepreneurial firms. First, Treisman (2000) finds that economic development has a causal effect on corruption. Also, Faccio (2006) uses GDP per capita as a proxy for economic development when analyzing the effects of political connections. We therefore separate the firms into two categories based on economic development: the 
first group is comprised of firms with their headquarters being located in provinces with low GDP per capita, while the other contains firms situated in relatively wealthier provinces. Second, we separate entrepreneurial firms into two groups based on the level of marketization in their respective location. Here, we use the National Economic Research Institute (NERI) Index of Marketization for China’s Provinces. ${ }^{3}$ Third, we follow an approach similar to that of Acemoglu et al. (2001) and divide China's provinces into two groups based on whether or not they were once leased to foreign powers for a significant period before 1949. The entrepreneurial firms are then separated into two groups depending on where their main operations are located. The main hypothesis is that lower real GDP per capita, lower levels of marketization, and territories that were never leased to industrial countries before 1949 are conducive for rent-seeking opportunities. Thus, political participation will have a more salient effect on firm performance in regions with more rent-seeking opportunities if the political participation really facilitates rent seeking.

\footnotetext{
${ }^{3}$ The NERI index focuses on provinces’ progress towards a market economy relative to other provinces. Each province is measured following a zero to ten score system. The index is based on 23 indicators of institutional arrangements and policies in five areas: size of the regional government; economic structure (growth of the non-state sector and the reform of state-controlled firms); inter-regional trade barriers; development of factor markets; and legal frameworks (Wang et al., 2007).
} 


\subsection{Descriptive Statistics}

Table 1 presents descriptive statistics for IPOs in China. Panel A shows the sample distribution by year. Overall, we have 265 IPO events by entrepreneurial firms. Column 5 in Panel A presents the percentage of IPOs by firms controlled by entrepreneurs who participate in politics out of total IPOs in each year. Out of the 265 entrepreneurial firms that conducted an IPO during 1994-2007, 67 (or 25.28\%) of them had a controlling entrepreneur or at least one of his or her family members that was a member of the CCCP, NPC, CPPCC, or one of their provincial branches. The ratio of entrepreneurial firms with political connections to the total number of entrepreneurial firms ranges from 0 to $44 \%$ depending on the year. There are IPOs carried out by firms controlled by entrepreneurs who participate in politics every year except for 1995 and 1997.

Panel B in Table 1 describes the industry distribution of the sample firms following the China Securities Regulatory Commission's (CSRC) classification standards. Of the 265 entrepreneurial firms that did an IPO during the sample period, a total of 185 are mainly active in the manufacturing sector. Similarly, most of the firms that are controlled by entrepreneurs who participate in politics (52 out of 67) are active in the manufacturing sector. For a few industries, such firms make out a majority of the total entrepreneurial firms that went public during the sample period. For example, in the mining and real estate sectors, all entrepreneurial firms that went public were controlled by entrepreneurs who participate in politics. However, it should be noted that the number of entrepreneurial IPOs in these sectors is very small. 
Table 2 provides summary statistics for firm characteristics in the two firm samples. The two sample groups exhibit significant differences in almost all firm characteristics during the IPO year. Looking at Tobin's Q, which we calculate as the sum of the market value of a firm's equity and book value of total liabilities divided by total assets at the end of the IPO year, it is evident that firms controlled by entrepreneurs who participate in politics have a higher Tobin's Q than other entrepreneurial firms. This suggests that investors value entrepreneurial political participation. If we instead look at Leverage, which equals total liabilities over total assets at the end of IPO year, it is clear that firms controlled by entrepreneurs who participate in politics have a higher leverage than other entrepreneurial firms. Looking at firm size, which is measured as the natural logarithm of total assets at the end of the IPO year, firms with entrepreneurial political participation are larger than firms which are not controlled by entrepreneurs who participate in politics. The only firm characteristic that is not statistically different for the two samples is that of Ownership, which is measured as the percentage of shares held by the largest shareholder. Although the average largest shareholder of firms with entrepreneurial political participation own a larger share of his or her firm than the major shareholder of common entrepreneurial firms, the difference between the two sample groups is not significant. 


\section{Political Participation and Firm Performance}

\subsection{Effect of Political Participation on Stock Performance}

We first investigate the impact that political participation has on stock performance of entrepreneurial firms. Here stock performance is measured as the cumulative abnormal returns (CARs), where the abnormal return is defined as marketadjusted monthly return. Market returns are calculated as equally-weighted monthly returns of all stocks on the Shanghai and Shenzhen stock exchanges. We analyze the impact over windows that range from one year to three years beginning one month after the IPO. Panel A in Table 3 reports the mean and median values for long-run stock performance after the IPO. The entrepreneurial firms are sorted in groups based on whether or not they are controlled by entrepreneurs who participate in politics. Both groups exhibit decreasing CARs over time. The mean CAR of firms controlled by entrepreneurs who participate in politics exhibits a modest decline of approximately 4.7\% over the first twelve months compared to a much steeper decline of close to $13.0 \%$ for the group of firms without such entrepreneurs. Similarly, the decline in the mean CAR after 36 months is approximately $12.4 \%$ for firms controlled by entrepreneurs who participate in politics and a much larger $30.0 \%$ for firms not controlled by such entrepreneurs. $T$-tests show that the mean CAR is significantly lower at the $5 \%$ level for the one- and two-year CARs and at the $1 \%$ level for the three-year CAR. Wilcoxon-Mann-Whitney test for differences in the median show that the median CAR is significantly lower at the $10 \%$ level after two and three years, respectively. The 
pattern of CARs is plotted in Figure 1. These initial findings are opposite to those of Fan et al. (2007), who showed that firms with political connections exhibit larger decreases in stock returns than firms without such connections. While the standard grabbing hand argument explains the SOEs' results in Fan et al. (2007), it does not provide a good explanation for our entrepreneurial results. From this initial comparison of the two groups of firms, it is evident that entrepreneurial firms without political participation experience much more drastic declines in stock performance after their IPO.

We also estimate ordinary least squares (OLS) regressions using the one-, two-, and three-year CARs as dependent variables. For our purpose, we focus on a dummy variable that is equal to one if the controlling entrepreneur participate in politics and zero otherwise. We also control for other firm-specific variables, including Ownership, Tobin's Q, Leverage, and Size. We also include industry and year dummies, but do not report them for the sake of brevity. Finally, we winsorize all continuous variables at the top and bottom $5 \%$ in order to minimize the effect of outliers.

Panel B in Table 3 presents the results of the multivariate regressions. We find that political participation is positively related to long-run stock performance at the $5 \%$ level for one- and two-year CARs and at the 1\% level for three-year CARs. Firms controlled by entrepreneurs who participate in politics outperform other entrepreneurial firms with $8.2 \%, 16.4 \%$, and $17.3 \%$ for one-, two-, and three-year CARs, respectively. For the other independent variables, it is only Tobin's Q and Firm Size that are significant, with a positive effect on long-run stock performance for both variables over 
all three time horizons. Overall, it is clear that political participation opens up new channels that can be used to create value for the firms controlled by entrepreneurs who participate in politics.

\subsection{Effect of Political Participation on Accounting Performance}

To further investigate the effects of political participation, we look at changes in post-IPO accounting performance measured as growth in sales, growth in earnings, and change in return on sales (ROS), respectively. Growth in sales (earnings) is calculated as the growth rate of sales (earnings) from the average annual sales (earnings) three years before to three years after the IPO. The change in ROS is calculated as the difference between the average annual ROS of the three years after and that of the three years before the IPO.

Panel A in Table 4 presents the results of the between-group tests for differences in the mean and median for firms controlled by entrepreneurs with or without political participation. The firms controlled by entrepreneurs participating in politics exhibit a significantly higher growth in sales, albeit only at the $10 \%$ significance level. Growth in earnings exhibits much stronger differences. Firms controlled by entrepreneurs that participate in politics have a significantly higher mean of growth in earnings at the $1 \%$ level and a higher median at the $10 \%$ level. Finally, the mean and median of ROS are higher for firms controlled by entrepreneurs who participate in politics, even though the difference is not statistically significant. Overall, we can tentatively conclude that the between-group results for accounting performance are supportive of the results we 
found for long-run stock performance. That is, firms controlled by entrepreneurs who participate in politics outperform other entrepreneurial firms.

To shed more light on the differences between the two groups, we perform multivariate regressions, the results of which are reported in Panel B in Table 4. Political participation has a significant positive effect on all three accounting performance measures. The coefficient for political participation is significant at the $5 \%$ level for growth in sales, at the $1 \%$ level for growth in earnings, and at the $10 \%$ level for change in ROS. These findings corroborate our results on long-run stock performance and suggest that political participation by entrepreneurs benefits the firms they control during IPO events. A natural next question is: do shareholders value political participation during the IPO pricing process?

\section{Underpricing of Entrepreneurial IPOs}

Having found that political participation contributes to firms' long-term performance, we also expect that it will play an important role in the pricing of shares during the IPO process. Firms with political participation do not need a significant underpricing if political participation can act as a credible signal for future performance. While IPO underpricing is a common feature around the world, underpricing in IPOs in China is usually extremely high (e.g., Chan et al., 2004; Fan et al., 2007; Tian and Megginson, 2007). Previous research has discussed this phenomenon from the perspective of political connections in China. However, existing studies mainly focus on state-controlled firms. For example, Fan et al. (2007) and Francis et al. (2009) both 
provide evidence that political connections reduce IPO underpricing for state-controlled firms. ${ }^{4}$ We instead analyze the relationship between political participation and underpricing for Chinese entrepreneurial IPOs.

Panel A in Table 5 presents the mean and median statistics of IPO underpricing for entrepreneurial firms. Underpricing is measured as the return on the first trading day, i.e. the difference between the first-day closing price and the offering price divided by the offering price. The table shows the mean and median for our groups of firms controlled by entrepreneurs with or without political participation. The mean first-day return for firms controlled by entrepreneurs who participate in politics is $102 \%$, compared to $151 \%$ for other entrepreneurial firms. There is a significant difference in both the mean (at the 1\% level) and median (at the 5\% level) values between the two groups.

Having documented the differences between underpricing in the two groups, we conduct a multivariate OLS regression to control for additional factors that may influence the size of IPO underpricing. The main independent variable in the regression is political participation. We also include a number of control variables commonly used in studies on underpricing: Market Return; Pre_Ownership, measured as the average annual ownership of the largest owner during three years prior to the IPO;

\footnotetext{
${ }^{4}$ Although Francis et al. (2009) also analyze IPO underpricing for non-state controlled firms, they do not find a significant difference between a very small sample of five such firms with political connections and 46 firms without political connections.
} 
Pre_Leverage, measured as the average annual leverage ratio during three years prior to the IPO; Pre_Size, measured as the natural logarithm of the average annual total assets during three years prior to the IPO; the P/E ratio, measured as the ratio of the offering price to earnings per share (EPS), where EPS is the ratio of the average annual earnings during three years before the IPO to the total number of post-offering shares; Underwriter's Rank, a dummy variable that equals one if the lead underwriter is ranked among the top ten in terms of total amount raised the year before the IPO and zero otherwise; Underwriting cost, measured as the ratio of total underwriting fees to total money raised; Proceeds, measured as the natural logarithm of the offering size; Days, measured as the number of days between offering and listing day. Panel A in Table 5 provides summary statistics for these pre-IPO firm characteristics in the two firm samples. Again, there is no significant difference in the size of the ownership of the largest shareholder. Turning to Leverage, there is no significant difference between firms with entrepreneurial political participation and common entrepreneurial firms. This stands in contrast to the general firm characteristics presented in Table 2, which showed that leverage at the end of the IPO year is significantly higher for firms controlled by entrepreneurs that participate in politics. This suggests that firms with entrepreneurial political participation increase their leverage faster than common entrepreneurial firms after the IPO. Firms controlled by entrepreneurs who participate in politics are again larger in size than common entrepreneurial firms. The $\mathrm{P} / \mathrm{E}$ ratio, Underwriter's rank, and Underwriting cost do not differ significantly between the two sample groups. Proceeds are significantly larger for firms controlled by entrepreneurs 
who participate in politics, a natural result since such firms are on average larger than other entrepreneurial firms. Finally, when comparing the two groups of entrepreneurial firms, there is no significant difference in the number of days from offering to listing day.

Panel B of Table 5 reports the results of the multivariate regression, which also includes industry and year dummies. Four of the control variables are significant: Market Returns, P/E ratio, Underwriting Cost, and Proceeds. Even when controlling for these additional potential factors, the effect of political participation is still significant at the 5\% level. Political participation thus has a significant negative influence on underpricing for entrepreneurial firms, which means that firms controlled by entrepreneurs who participate in politics leave less money on the table. One reason for this is that political participation signals additional value and for such firms. As noted earlier, if entrepreneurial firms are connected through the political participation by the controlling entrepreneurs, they are more likely to report better accounting performance and reward their shareholders with higher stock prices in the future. It is therefore not necessary for such firms to leave as much money on the table during their public offerings as other entrepreneurial firms do, a result that supports the recognition of the value of political participation in the IPO process.

\section{Institutional effect on the value of political participation}

Our results so far are in favor of political participation having a significant effect on firm stock and accounting performance as well on underpricing for Chinese 
entrepreneurial firms that goes public. We have argued that this effect may be a sign of the existence of rent seeking, with firms that are controlled by entrepreneurs who participate in politics extracting additional rent through their political ties. However, the effect may also be due to the possibility that entrepreneurs who are selected to become members of the different political congresses are actually more capable at what they do. Our empirical evidence so far cannot help us differentiate between these two possible effects. Here, we therefore take rent-seeking opportunities, measured by regional institution, into account. We argue that if the effect is larger in regions with more opportunities for rent seeking, it will indicate that the difference is due to rent seeking rather than entrepreneurial ability alone. We thus conduct similar tests to those in the previous sections, adding the three proxies for rent-seeking opportunities introduced in Section 3.3.

\subsection{Regression Analysis for Long-Run Stock Performance}

Table 6 reports the results of the multivariate regressions with the three-year CAR as the dependent variable. The first column presents the effect of political participation on long-run stock performance when using real GDP per capita as institutional dummy. The control variables are the same as in Section 4.1. The results show that political participation is still statistically significant at the $5 \%$ level for the three-year CARs. Institutions by themselves do not have a significant effect on long-run stock performance at any time horizon. However, we also include an interactive variable between Political Participation and Institutions. The interactive variable is significant at 
the $5 \%$ level. This indicates that the value of political participation is more valuable in underdeveloped regions, which tend to exhibit more rent-seeking opportunities. The second column in Table 6 shows the results of a similar multivariate regression in which institutions are proxied by the level of marketization in the region of a firm's headquarters. The coefficient for political participation is again significant and positive at the $5 \%$ level. Institutions by themselves are not significant. However, the coefficient for the interactive variable of political participation and institutions is once more significant.

Finally, the third column in Table 6 presents the results for the multivariate regression in which local institutions are proxied by whether or not the province in which the firms have their headquarters was leased to a foreign power before 1949 . Political participation remains significant and positive, although the coefficient for political participation is only significant at the $10 \%$ level. Institutions by themselves are not significant, while the interactive variable for political participation and institutions is again significant.

To sum up the results, the three proxies for rent-seeking opportunities have a significant effect on the ability for entrepreneurial firms to exploit their networks gained through political participation for rent-seeking activities. These proxies themselves do not have a significant effect on stock performance. However, the interactive variable combining rent-seeking opportunities and political participation does have a significant positive effect, indicating that political participation increases the possibilities for rent seeking more in areas with weaker institutions. 


\subsection{Regression Analysis for Changes in Accounting Performance}

Table 7 presents the regression results of the effects of political participation on changes in accounting performance after an IPO. Columns 1-3 report the results using regional GDP per capita levels as institutional factor. The effect of political participation remains positive and significant for all accounting performance measures except the change in ROS. The dummy variable for low real GDP is not significant for entrepreneurial firms' accounting performance. However, the interactive variable for political participation and GDP per capita levels is significant at the 5\% level for both growth in earnings and the change in ROS.

Columns 4-6 in Table 7 present the results for the multivariate regressions with level of marketization as the institutional factor. The effect of political participation is again significant at the $5 \%$ level for growth in sales. It is no longer significant for growth in earnings. However, the interactive variable for political participation and marketization is significant for both growth in earnings and the change in ROS. Finally, Columns 7-9 present the results for regressions with dummy variables for whether or not the region in which the entrepreneurial firm in question was leased to a foreign power before 1949. Again, the effect of political participation is significant and positive at the $5 \%$ level for growth in sales and at the $10 \%$ level for growth in earnings. The interactive variable for political participation and local institutions is now significant and positive for all three measures of accounting performance.

Overall, our findings again indicate that institutions are important for entrepreneurial firms and their changes in accounting performance after an IPO. The 
results in the multivariate regressions show that institutions on their own do not have a significant effect on accounting performance. However, the opportunities for rent seeking through political participation are positively related to the level of institutions. Rent-seeking opportunities are thus important for entrepreneurial firms in China, but in order to exploit such opportunities, firms need to develop relationships with the political leadership. One way to obtain such relationships is through political participation by the controlling entrepreneur or by his or her family members.

\section{Conclusion}

This paper examines the impact of political participation on entrepreneurial firms that went public in China during 1994-2007. The empirical results show that political participation by the controlling entrepreneurs or their family members has a significant positive effect on post-IPO stock and accounting performance. Moreover, political participation is related to lower levels of underpricing for Chinese entrepreneurial IPOs. The effect of political participation on firm performance is stronger in regions with weaker institutions, which allow for richer rent-seeking opportunities.

Our results are consistent with the rent-seeking hypothesis arguing that political participation by entrepreneurs facilitates rent seeking. While China's transition from a planned to a market economy is unique in many ways, the results in this paper may be useful when analyzing other developing economies that similarly have entrepreneurs who participate in politics, weak institutions, and ample opportunities for rent seeking. 


\section{References}

Acemoglu, D., Johnson, S., Robinson, J., 2001. The colonial origins of comparative development: an empirical investigation. American Economic Review 91, 1369-1401.

Allen, F., Qian, J., Qian, M., 2005. Law, finance and economic growth in China. Journal of Financial Economics 77, 57-116.

Baumol, W., 1990. Entrepreneurship: productive, unproductive, and destructive. Journal of Political Economy 98, 893-921.

Beck, T., Levine, R., 2002. Industry growth and capital allocation: Does having a market- or bank-based system matter? Journal of Financial Economics 64, 147-180.

Benmelech, E., Moskowitz, T., 2010. The political economy of financial regulation: Evidence from U.S. state usury laws in the 19th Century. Journal of Finance, 3, 10291073.

Buchanan, J.M., 1980. Rent seeking and profit seeking, in: Buchanan, J.M.,Tollison, R.D., Tullock, G. (Eds) Toward a theory of the rent-seeking society. College Station, TX: Texas A\&M University Press.

Calomiris, C.W., Fisman, R., Wang, Y., 2010. Profiting from government stakes in a command economy: Evidence from Chinese asset sales. Journal of Financial Economics 96, 399-412.

Chan, K., Wang, J., Wei, K.C.J., 2004. Underpricing and long-term performance of IPOs in China. Journal of Corporate Finance 10, 409-430.

Charumilind, C., Kali, R., Wiwattanakantang, Y., 2006. Connected lending: Thailand before the financial crisis. Journal of Business 79, 181-218.

Che, J., Qian, Y., 1998. Insecure property rights and government ownership of firms. Quarterly Journal of Economics 113, 467-496.

Chen, J., Dickson, B.J., 2010. Allies of the state: China's private entrepreneurs and democratic change. Cambridge, MA: Harvard University Press.

Claessens, S., Feijen, E., Laeven, L., 2008. Political connections and preferential access to finance: The role of campaign contributions. Journal of Financial Economics 88, 554-580. 
Demirgüç-Kunt, A., Maksimovic, V., 1998. Law, finance, and firm growth. Journal of Finance 53, 2107-2137.

Dinc, I.S., 2005. Politicians and banks: Political influence on government-owned banks in emerging markets. Journal of Financial Economics 77, 453-479.

Djankov, S., Qian, Y., Roland, G., Zhuravskaya, E., 2006. Who are China’s entrepreneurs? American Economic Review 96, 348-352.

Dougherty, S., Herd, R., He, P., 2007. Has a private sector emerged in China's industry? Evidence from a quarter of a million Chinese firms. China Economic Review 18, 309-334.

Faccio, M., 2006. Politically connected firms. American Economic Review 96, 369-386.

Faccio, M., Masulis, R.W., McConnell, J.J., 2006. Political connections and corporate bailouts. Journal of Finance 61, 2597-2635.

Faccio, M., and D. Parsley. 2007. Sudden death: Taking stock of geographic ties. Working Paper No. 113/2006 (Finance), ECGI.

Fan, J.P.H., Wong, T.J., Zhang, T., 2007. Politically connected CEOs, corporate governance, and post-IPO performance of China's newly partially privatized firms. Journal of Financial Economics 84, 330-357.

Ferguson, T., Voth, H.-J., 2008. Betting on Hitler - The value of political connections in Nazi Germany. Quarterly Journal of Economics 123, 101-137.

Fisman, R., 2001. Estimating the value of political connections. American Economic Review 91, 1095-1102.

Francis, B.B., Hasan, I., Sun, X., 2009. Political connections and the process of going public: Evidence from China. Journal of International Money and Finance 28, 696-719.

Goldman, E., Rocholl, J., So, J., 2009. Do politically connected boards affect firm value? Review of Financial Studies 22, 2331-2360.

Hall, R., Jones, C., 1999. Why do some countries produce so much more output per worker than others? Quarterly Journal of Economics 114, 83-116.

Huang, Y., 2008. Capitalism with Chinese Characteristics: Entrepreneurship and the State. New York: Cambridge University Press. 
Jayachandran, S., 2006. The Jeffords effect. Journal of Law and Economics 49, 397425.

Johnson, S., Mitton, T., 2003. Cronyism and Capital Controls: Evidence from Malaysia. Journal of Financial Economics 67, 351-382.

Khwaja, A., Mian, A., 2005. Do lenders favor politically connected firms? Rent provision in an emerging financial market. Quarterly Journal of Economics 120, 13711411.

Knight, B., 2006. Are policy platforms capitalized into equity prices? Evidence from the Bush/Gore 2000 presidential election. Journal of Public Economics 90, 751-773.

Kroszner, R. S., Stratmann, T.E., 1998. Interest-group competition and the organization of Congress: Theory and evidence from financial services’ political action committees. American Economic Review 88, 1163-1187.

Krueger, A., 1974. The political economy of the rent-seeking society. American Economic Review 64, 291-303.

La Porta, R., Lopez-de-Silanes, F., Shleifer, A., 1999. Corporate ownership around the world. Journal of Finance 54, 471-518.

La Porta, R., Lopez-de-Silanes, F., Shleifer, A., Vishny, R., 2002. Investor protection and corporate valuation. Journal of Finance 57, 1147-1170.

Li, D.D., 1996. A theory of ambiguous property rights in transition economies: The case of the Chinese non-state sector. Journal of Comparative Economics 23, 1-19.

Li, D.D., Feng, L., Jiang, H., 2006. Institutional entrepreneurs. American Economic Review 96, 358-362.

Li, H., Meng, L., Wang, Q., Zhou, L.-A., 2008. Political connections, financing and firm performance: Evidence from Chinese private firms. Journal of Development Economics 87, 283-299.

Mauro, P., 1995. Corruption and growth.Quarterly Journal of Economics 110, 681-711.

Murphy, K.M., Shleifer, A., Vishny, R.W., 1991. The allocation of talent: Implications for growth. Quarterly Journal of Economics 106, 503-530.

Murphy, K.M., Shleifer, A., Vishny, R., 1993. Why is rent-seeking so costly to growth? American Economic Review, Papers and Proceedings 83, 409-414. 
Naugthon, B., 1994. Chinese institutional innovation and privatization from below. American Economic Review, Papers and Proceedings 84, 266-270.

Naughton, B., 2007. The Chinese Economy: Transitions and growth. Cambridge, MA: MIT Press.

Rajan, R., Zingales, L., 2003. The Great Reversals: The politics of financial development in the 20th century. Journal of Financial Economics 69, 5-50.

Roberts, B., 1990. A dead senator tells no lies: Seniority and the distribution of Federal benefits. American Journal of Political Science 34, 31-58.

Shambaugh, D., 2009. China's Communist Party: Atrophy and adaptation. Berkeley, CA: The University of California Press.

Shleifer, A., Vishny, R., 1986. Large shareholders and corporate control. Journal of Political Economy 94, 461-488.

Shleifer, A., Vishny, R., 1994. Politicians and firms. Quarterly Journal of Economics 109, 995-1025.

Shleifer, A., Vishny, R., 1998. The grabbing hand: Government pathologies and their cures. Cambridge, MA: Harvard University Press.

Treisman, D., 2000. The causes of corruption: A cross-national study. Journal of Public Economics 76, 399-457.

Tian, L., Megginson, W.L., 2007. Regulatory underpricing: determinants of Chinese extreme IPO returns. Working Paper, University of Oklahoma.

Tsai, E.S., 2007. Capitalism without democracy: The private sector in contemporary China. Ithaca, NY: Cornell University Press.

Wang, X., Fan, G., Zhu, H., 2007. Marketisation in China: progress and contribution to growth, in: Garnaut, R., Song, L. (Eds) China linking markets for growth. Canberra: ANU E Press and Asia Pacific Press.

Weitzman, M.L., Xu, C., 1994. Chinese township-village enterprises as vaguely defined enterprises. Journal of Comparative Economics 18, 121-145.

Wright, T., 2010. Accepting authoritarianism: State-society relations in China's reform era. Stanford, CA: Stanford University Press. 
Figure 1 Mean monthly cumulative abnormal returns

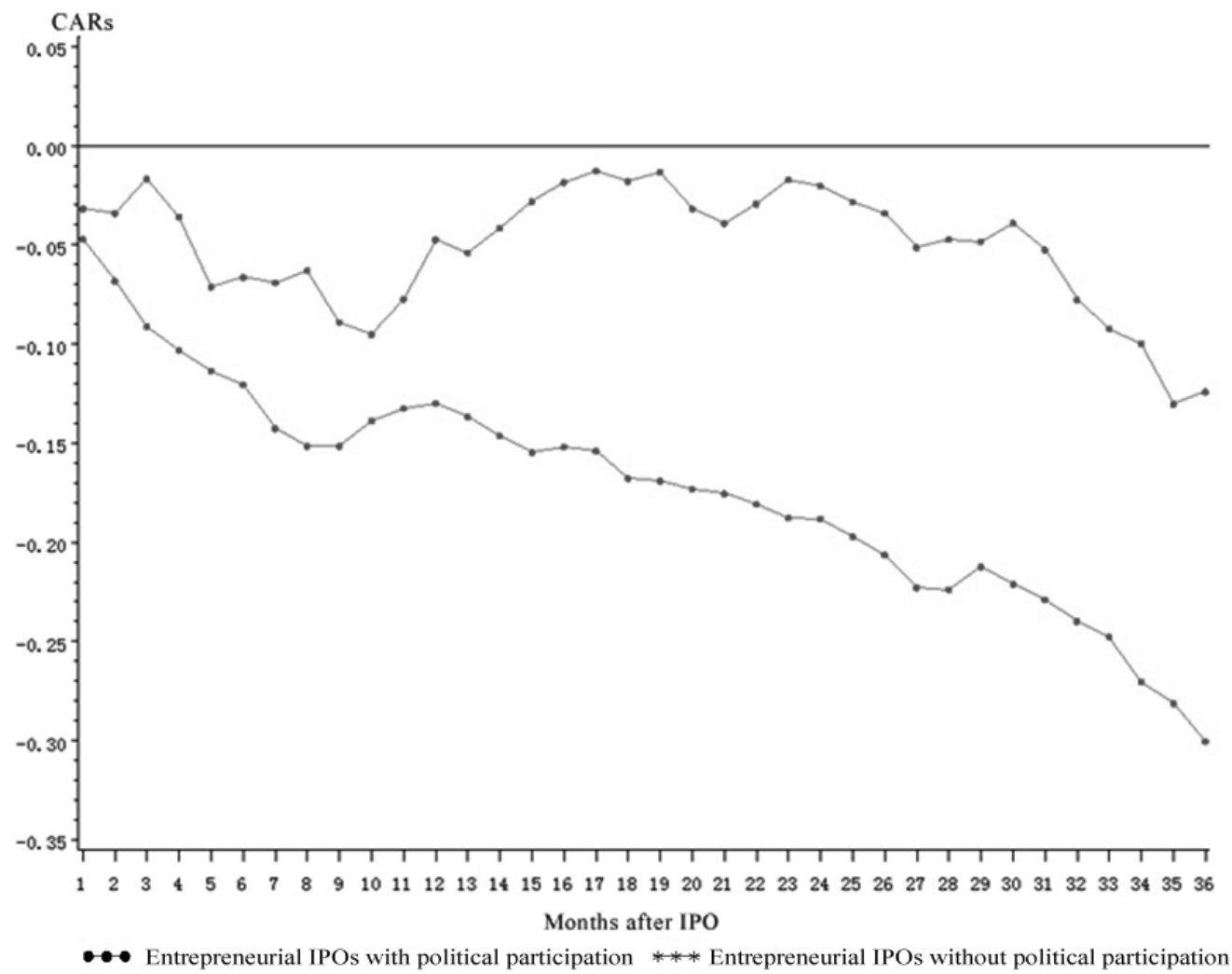

This figure presents the market-adjusted cumulative abnormal returns (CARs), starting from one month after the IPO month and sorted by whether or not the controlling entrepreneur participate in politics before the IPO event. 


\section{Table 1}

\section{The sample}

\section{Panel A: Distribution of entrepreneurial IPOs}

This panel presents the distribution of entrepreneurial IPOs by year during 1993-2007. Entrepreneurial firms refer to corporations controlled by entrepreneurs (or their families) at the time of the IPO. Columns 2-3 report the number of entrepreneurial IPOs and entrepreneurial firms as the percentage of the total IPO population respectively. Columns 4 and 5 present the number of entrepreneurial IPOs with political participation and such firms as a percentage of total entrepreneurial IPOs, respectively. Political participation is defined as the controlling entrepreneur (or their family members) being a member of the National People's Congress (NPC), the Chinese People's Political Consultative Conference (CPPCC), or the Congress of Chinese Communist Party (CCCP) before the IPO event.

\begin{tabular}{cccccc}
\hline & \multicolumn{2}{c}{$\begin{array}{c}\text { Entrepreneurial IPOs } \\
\text { Year }\end{array}$} & & & \multicolumn{2}{c}{$\begin{array}{c}\text { Entrepreneurial IPOs } \\
\text { with political participation }\end{array}$} \\
\cline { 2 - 3 } \cline { 5 - 6 } & $\mathrm{N}$ & $\begin{array}{c}\text { As percentage of all } \\
\text { IPOs (\%) }\end{array}$ & & $\mathrm{N}$ & $\begin{array}{c}\text { As percentage of all } \\
\text { entrepreneurial IPOs (\%) }\end{array}$ \\
\hline 1994 & 11 & 10.00 & & 2 & 18.18 \\
1995 & 1 & 4.17 & & 0 & 0.00 \\
1996 & 10 & 4.93 & & 2 & 20.00 \\
1997 & 13 & 6.31 & & 0 & 0.00 \\
1998 & 7 & 6.60 & & 3 & 42.86 \\
1999 & 9 & 9.18 & & 3 & 33.33 \\
2000 & 17 & 12.41 & & 6 & 35.29 \\
2001 & 13 & 16.46 & & 3 & 23.08 \\
2002 & 10 & 14.08 & & 3 & 30.00 \\
2003 & 22 & 32.84 & & 8 & 36.36 \\
2004 & 41 & 41.00 & & 18 & 43.90 \\
2005 & 7 & 46.67 & & 2 & 28.57 \\
2006 & 30 & 45.45 & & 8 & 26.67 \\
2007 & 74 & 58.73 & & 9 & 12.16 \\
\hline Total & 265 & 18.82 & 67 & 25.28 \\
\hline
\end{tabular}




\section{Table 1 (Continued)}

The sample

Panel B: Distribution of entrepreneurial IPOs with political participation by industry

This panel presents the distribution of entrepreneurial IPOs with political participation. Political participation is defined as the controlling entrepreneur (or their family members) becoming a member of the National People's Congress (NPC), the Chinese People's Political Consultative Conference (CPPCC), or the Congress of Chinese Communist Party (CCCP) before the IPO event.

\begin{tabular}{|c|c|c|c|c|}
\hline & \multicolumn{2}{|c|}{ Entrepreneurial IPOs } & \multicolumn{2}{|c|}{$\begin{array}{c}\text { Entrepreneurial IPOs } \\
\text { with political } \\
\text { participation } \\
\end{array}$} \\
\hline & $\mathrm{N}$ & $\begin{array}{c}\text { As } \\
\text { percentage } \\
\text { of all IPOs } \\
(\%)\end{array}$ & $\mathrm{N}$ & $\begin{array}{l}\text { As percentage } \\
\text { of all } \\
\text { entrepreneurial } \\
\text { IPOs (\%) }\end{array}$ \\
\hline $\begin{array}{l}\text { Agriculture, forestry, } \\
\text { farming and fishery }\end{array}$ & 6 & 15.00 & 3 & 50.00 \\
\hline Mining & 1 & 2.86 & 1 & 100.00 \\
\hline Manufacturing & 185 & 21.84 & 52 & 28.11 \\
\hline Utilities & 1 & 1.82 & 0 & 0.00 \\
\hline Construction & 6 & 20.00 & 2 & 33.33 \\
\hline Transportation & 4 & 6.45 & 2 & 50.00 \\
\hline Information Technology & 32 & 38.55 & 2 & 6.25 \\
\hline Wholesale and retail trade & 3 & 3.95 & 1 & 33.33 \\
\hline Real estate & 2 & 8.00 & 2 & 100.00 \\
\hline Social Services & 3 & 7.50 & 0 & 0.00 \\
\hline Miscellaneous & 22 & 25.00 & 2 & 9.09 \\
\hline Total & 265 & 18.82 & 67 & 25.28 \\
\hline
\end{tabular}




\section{Table 2}

\section{Characteristics of firms controlled by entrepreneurs with and without political}

\section{participation}

This table presents the summary statistics for entrepreneurial firms, distinguished by whether their entrepreneurs participated in politics before the IPO. Ownership is the percentage ownership of the largest owner at the end of the IPO year. Tobin's Q is measured as the sum of total market valuation of equities and total net liabilities divided by total assets at the end of the IPO year. Leverage is measured as the ratio of total liabilities over total assets at the end of the IPO year. Firm size is measured as the natural logarithm of total assets at the end of the IPO year. T-tests and WilcoxonMann-Whitney tests are provided for comparison of the mean and median of firm and IPO characteristics between entrepreneurial firms with and without political participation. ***,**, and * denote significance at the $1 \%, 5 \%$ and $10 \%$ level, respectively.

\begin{tabular}{lcccccc}
\hline & \multicolumn{3}{c}{ Political participation } & \multicolumn{3}{c}{ No political participation } \\
& $\mathrm{N}$ & Mean & Median & $\mathrm{N}$ & Mean & Median \\
\hline Ownership & 67 & 0.399 & 0.403 & 198 & 0.371 & 0.363 \\
Tobin’s Q & 67 & $3.676^{* * *}$ & $3.476^{* * *}$ & 198 & 2.859 & 2.566 \\
Leverage & 67 & $0.361^{* *}$ & $0.359^{* *}$ & 198 & 0.320 & 0.322 \\
Firm size & 67 & $20.636^{* * *}$ & $20.463^{* * *}$ & 198 & 20.216 & 20.189 \\
\hline
\end{tabular}




\section{Table 3}

\section{Effects of political participation on stock performance}

Panel A: Univariate tests

This panel presents univariate tests for stock performance after the IPO, sorted by whether or not their entrepreneurs had political participation before the event. Stock performance is measured as the one-, two-, and three-year market-adjusted cumulative abnormal returns (CARs), starting one month after the IPO month. T-tests and the Wilcoxon-Mann-Whitney tests are provided for the difference between entrepreneurial IPOs by firms with and without political participation. ***, **, and * denote significance at the $1 \%, 5 \%$ and $10 \%$ level, respectively.

\begin{tabular}{lcccccc}
\hline & \multicolumn{3}{c}{ Political participation } & \multicolumn{3}{c}{ No political participation } \\
& $\mathrm{N}$ & Mean & Median & $\mathrm{N}$ & Mean & Median \\
\hline & & & & & & \\
CARs 1 year & 67 & $-0.047^{* *}$ & -0.039 & 198 & -0.130 & -0.113 \\
CARs 2 year & 67 & $-0.020^{* *}$ & $-0.015^{*}$ & 198 & -0.188 & -0.184 \\
CARs 3 year & 67 & $-0.124^{* * *}$ & $-0.113^{*}$ & 198 & -0.300 & -0.232 \\
& & & & & & \\
\hline
\end{tabular}


Table 3 (continued)

Effects of political participation on stock performance

Panel B: Multivariate analysis

This table presents OLS regressions in which the dependent variable is alternatively measured as the 1-, 2-, and 3-year market-adjusted cumulative abnormal returns (CARs), starting one month after the IPO month. The independent variables are: Political participation, which equals one if their entrepreneurs had political participation before the IPO event and zero otherwise; Ownership, measured as the percentage ownership of the largest owner; Tobin's Q, measured as the sum of total market valuation of equities and total net liabilities divided by total assets; Leverage, measured as the ratio of total liabilities over total assets; Size, measured as natural logarithm of total assets during the IPO year. Industry and year dummies are also included but not reported. Robust $t$-statistics are given in parentheses. All continuous variables are winsorized at top and bottom 5\%. ${ }^{* * *}$, **, and * denote significance at the $1 \%, 5 \%$ and $10 \%$ level, respectively.

\begin{tabular}{lccc}
\hline & $\begin{array}{c}\text { CAR one year } \\
\text { after IPO }\end{array}$ & $\begin{array}{c}\text { CAR two years } \\
\text { after IPO }\end{array}$ & $\begin{array}{c}\text { CAR three years } \\
\text { after IPO }\end{array}$ \\
\hline Political participation & $0.082^{* *}$ & $0.164^{* *}$ & $0.173^{* * *}$ \\
& $(2.16)$ & $(2.28)$ & $(2.71)$ \\
Ownership & -0.100 & -0.234 & -0.457 \\
& $(-0.63)$ & $(-1.21)$ & $(-0.87)$ \\
Tobin's Q & $0.073^{* * *}$ & $0.056^{* * *}$ & $0.042^{* *}$ \\
& $(4.02)$ & $(2.55)$ & $(2.01)$ \\
Leverage & -0.122 & -0.074 & -0.307 \\
& $(-0.66)$ & $(-0.33)$ & $(-0.71)$ \\
Firm size & $0.127^{* * *}$ & $0.137^{* *}$ & $0.136^{*}$ \\
& $(2.71)$ & $(2.46)$ & $(1.90)$ \\
Intercept & $-2.665^{* * *}$ & $-2.681^{* *}$ & $-2.582^{*}$ \\
& $(-2.91)$ & $(-2.40)$ & $(-1.83)$ \\
Industry indicators & Yes & Yes & Yes \\
Year indicators & Yes & Yes & Yes \\
\hline $\mathrm{N}$ & 265 & 265 & 265 \\
Adjusted $R^{2}$ & 0.350 & 0.329 & 0.371 \\
\hline
\end{tabular}




\section{Table 4}

\section{Effect of political participation on accounting performance}

\section{Panel A: Univariate tests}

This panel presents univariate tests for changes in accounting performance after the IPO, sorted by whether or not the controlling entrepreneur or (his family members) had political participation before the event. Growth of sales (earnings) is measured as the growth rates of sales (earnings) from the average annual sales (earnings) of three years before the IPO to that of three years after the event. Change in return on sales (ROS) is the difference between the average annual ROS of the three years after the IPO and that of the three years before the event. All variables are winsorized at top and bottom 5\%. T-tests and Wilcoxon-Mann-Whitney tests are provided for the difference between entrepreneurial firms with and without political connections. ***, $* *$, and $*$ denote significance at the $1 \%, 5 \%$ and $10 \%$, respectively.

\begin{tabular}{lcccccc}
\hline & \multicolumn{3}{c}{ Political participation } & \multicolumn{3}{c}{ No political participation } \\
& $\mathrm{N}$ & Mean & Median & $\mathrm{N}$ & Mean & Median \\
\hline & & & & & & \\
Growth in sales & 64 & $0.950^{*}$ & 0.927 & 182 & 0.837 & 0.796 \\
Growth in earnings & 64 & $0.620^{* * *}$ & $0.736^{*}$ & 182 & 0.199 & 0.569 \\
Change in ROS & 64 & -0.033 & -0.022 & 182 & -0.041 & -0.03 \\
& & & & & & \\
\hline
\end{tabular}


Table 4 (continued)

\section{Effect of political participation on accounting performance}

\section{Panel B: Multivariate analysis}

This table presents the OLS regressions in which the dependent variables is, alternately, growth in sales, growth in earnings, and change in return on sales (ROS). The independent variables include political participation, which equals one for firms with political participation before the IPO and zero otherwise, Tobin's Q, measured as the sum of total market valuation of equities and total net liabilities divided by total sales in the IPO year, leverage, measured as the ratio of total liabilities over total sales in the IPO year, and size, measured as natural logarithm of total sales in the IPO year. Sales are used instead of assets as denominator due to the effect of IPO on assets. Industry and year dummies are included but not reported. All continuous variables are winsorized at top and bottom $5 \%$. Robust $t$-statistics are given in parentheses. ${ }^{* * *}$,** ,and $*$ denote significance at the $1 \%, 5 \%$ and $10 \%$, respectively.

\begin{tabular}{lccc}
\hline & Growth & Growth & Change \\
& in sales & in earnings & in ROS \\
\hline Political participation & $0.071^{* *}$ & $0.502^{* * *}$ & $0.008^{*}$ \\
& $(1.98)$ & $(2.72)$ & $(1.87)$ \\
Ownership & 0.101 & -0.071 & -0.025 \\
& $(0.46)$ & $(-0.13)$ & $(-0.87)$ \\
Leverage & $0.274^{* * *}$ & 0.062 & $-0.040^{* * *}$ \\
& $(3.57)$ & $(0.31)$ & $(-3.89)$ \\
Firm size & $0.111^{* * *}$ & $0.173^{*}$ & $0.015^{* * *}$ \\
& $(2.85)$ & $(1.74)$ & $(2.79)$ \\
Tobin's Q & $0.074^{* * *}$ & $0.146^{* * *}$ & 0.001 \\
& $(3.59)$ & $(2.78)$ & $(0.44)$ \\
Intercept & $-2.021^{*}$ & $-4.210^{* *}$ & $-0.303^{* * *}$ \\
& $(-2.50)$ & $(-2.03)$ & $(-2.79)$ \\
Industry indicators & Yes & Yes & Yes \\
Year indicators & Yes & Yes & Yes \\
\hline $\mathrm{N}$ & 246 & 246 & 246 \\
Adjusted $R^{2}$ & 0.157 & 0.069 & 0.165 \\
\hline
\end{tabular}




\section{Table 5}

\section{Effect of Political Participation on IPO underpricing}

Panel A: Univariate Test

This table reports the descriptive statistics of IPO underpricing and control variables for entrepreneurial firms in China during 1994-2007, distinguished by whether or not the entrepreneurs had political participation before the event. Underpricing is measured as the difference between the closing price on the first trading day and the offering price, divided by the offering price. Pre_Ownership is the average annual ownership of the largest owner during the three years prior to the offering. Pre_Leverage is measured as the average annual leverage ratio during three years before the IPO. Pre_ size is measured as the natural logarithm of the average annual total assets during three year before the IPO. P/E ratio is measured as the ratio of the offering price to earnings per share (EPS), where EPS is the ratio of the average annual earnings during three years before the IPO to the total number of post-offering shares. Underwriter's Rank is a dummy variable that equals one if the lead underwriter is ranked among the top 10 in terms of total amount raised the year before the IPO and 0 otherwise. Underwriting Cost is measured as the ratio of total underwriting fees to total money raised. Proceeds is the natural logarithm of the offering size. Days is the number of days between the offering and listing day. All continuous variables are winsorized at the top and bottom 5\%. T-tests and WilcoxonMann-Whitney tests are provided for the comparison of the mean and median of firm and IPO characteristics between entrepreneurial firms with and without political connections. $* * *, * *$, and $*$ denote significance at the $1 \%, 5 \%$ and $10 \%$ level, respectively.

Panel A: Underpricing for entrepreneurial firms

\begin{tabular}{|c|c|c|c|c|c|c|}
\hline & \multicolumn{3}{|c|}{ Political participation } & \multicolumn{3}{|c|}{ No political participation } \\
\hline & $\mathrm{N}$ & Mean & Median & $\mathrm{N}$ & Mean & Median \\
\hline Underpricing & 67 & $1.02 * * *$ & $0.871 * *$ & 190 & 1.514 & 1.217 \\
\hline Pre_Ownership & 67 & 0.563 & 0.550 & 190 & 0.517 & 0.503 \\
\hline Pre_Leverage & 67 & 0.566 & 0.573 & 190 & 0.550 & 0.567 \\
\hline Pre_size & 67 & $19.704^{* * *}$ & $19.525 * *$ & 190 & 19.404 & 19.372 \\
\hline $\mathrm{P} / \mathrm{E}$ ratio & 67 & 33.217 & 31.443 & 190 & 34.042 & 32.459 \\
\hline Underwriter's rank & 67 & 0.308 & 0 & 190 & 0.356 & 0 \\
\hline Underwriting cost & 67 & 0.038 & 0.045 & 190 & 0.045 & 0.046 \\
\hline Proceeds & 67 & $19.635^{* * *}$ & $19.615 * * *$ & 190 & 19.333 & 19.331 \\
\hline Days & 67 & 21.326 & -14.000 & 190 & 21.978 & 15.000 \\
\hline
\end{tabular}




\section{Table 5 (continued)}

\section{Effect of Political Participation on IPO underpricing}

\section{Panel B: Multivariate test}

This table reports OLS regressions with underpricing as the dependent variable. The independent variables are: Political participation, which equals one if the entrepreneur had political participation before the IPO and zero otherwise; Market return, measured as equally weighted cumulated returns for all stocks traded in China from the offering day to the listing day; Pre_Ownership, the average annual ownership of the largest owner during the three years prior to the offering; Pre_Leverage, the leverage ratio measured as the average annual leverage ratio during the three years prior to the offering; Pre_Size, measured as the natural logarithm of average annual total assets during the three years prior to the offering; Pre_P/E ratio, measured as the ratio of offering price to earnings per share; Underwriter's rank, a dummy variable equal to one if the lead underwriter is ranked among the top ten underwriters; Underwriting cost, measured as the ratio of total underwriting fees to total money raised; Proceeds, the natural logarithm of the offering size; Days, the number of days between the offering and listing day. Industry and year dummies are included but not reported. Robust $t$-statistics are given in parentheses. All continuous variables are winsorized at the top and bottom 5\%. ***, **, and * denote significance at the $1 \%, 5 \%$ and $10 \%$, respectively. .

\begin{tabular}{lc}
\hline & Underpricing \\
\hline Political participation & $-0.269^{* *}$ \\
Market return & $(-1.98)$ \\
& $2.414^{* * *}$ \\
Pre_Ownership & $(4.14)$ \\
Pre_Leverage & 0.376 \\
& $(1.33)$ \\
Pre_Size & 0.157 \\
& $(0.37)$ \\
P/E ratio & 0.038 \\
& $(0.17)$ \\
Underwriter's rank & $0.010^{* * *}$ \\
& $(2.61)$ \\
Underwriting cost & 0.081 \\
& $(0.65)$ \\
Proceeds & $4.205^{*}$ \\
& $(1.91)$ \\
Days & $-0.431^{* * *}$ \\
& $(-3.22)$ \\
Intercept & 0.001 \\
& $(0.38)$ \\
Industry indicators & $9.573^{* * *}$ \\
Year indicators & $(3.10)$ \\
N & Yes \\
Adjusted $R^{2}$ & Yes \\
\hline & 257 \\
& 0.186 \\
\hline
\end{tabular}




\section{Table 6}

\section{Effects of Institutions on the association between political participation and stock}

performance

This table presents the OLS regression results of the effects of political participation on stock performance, sorted by local institutions. The dependent variable is, alternatively, measured as cumulative market-adjusted abnormal returns (CARs) for three years, starting from one month after the IPO. The independent variables are: Political participation, which equals one if the controlling entrepreneur has political participation before the IPO event and zero otherwise; Proxies for local institutions; the interaction of political connections and institutions; Ownership, measured as the percentage ownership of the largest owner; Tobin's Q, measured as the sum of total market valuation of equities and total net liabilities divided by total assets; Leverage, measured as the ratio of total liabilities over total assets; Size, measured as natural logarithm of total assets in the IPO year.

Proxies for institutions are: GDP per capita, measured as above or below the sample median value of local average real GDP per capita during 1979-2007 (Institutions equal one if local GDP per capita is below the sample median value and zero otherwise); Marketization, based on whether or not the firm's headquarter is from a relatively more developed region, using the National Economic Research Institute (NERI) Index of Marketization for China's provinces (Institutions equal one if a firm's headquarter is located in a less well developed region and zero otherwise); Leased provinces, based on whether or not the firm's headquarter are located in province that was once leased to industrial countries before 1949 (Institutions equal one if a firm's headquarter is located in a province that was never leased to foreign powers countries before 1949 and zero otherwise). Industry and year dummies are also included but not reported. Robust $t$-statistics are given in parentheses. All continuous variables are winsorized at the top and bottom $5 \%$. ***, **, and * denote significance at the $1 \%, 5 \%$ and $10 \%$ level, respectively. 
Table 6 (continued)

Effects of Institutions on the association between political participation and stock performance

\begin{tabular}{lccc}
\hline Institutional proxy & $\begin{array}{c}\text { GDP per } \\
\text { capita }\end{array}$ & Marketization & $\begin{array}{c}\text { Leased } \\
\text { provinces }\end{array}$ \\
\hline Political participation & $0.023^{* *}$ & $0.070^{* *}$ & $0.068^{*}$ \\
Institutions & $(2.25)$ & $(2.32)$ & $(1.77)$ \\
& -0.002 & -0.011 & -0.012 \\
Political participation*Institutions & $(-0.84)$ & $(-0.49)$ & $(-0.71)$ \\
& $0.160^{* *}$ & $0.104^{* *}$ & $0.101^{* *}$ \\
Ownership & $(2.18)$ & $(2.16)$ & $(2.07)$ \\
& $-0.451^{*}$ & $-0.452^{*}$ & $-0.461^{*}$ \\
Tobin's Q & $(-1.85)$ & $(-1.84)$ & $(-1.88)$ \\
& 0.037 & 0.040 & 0.041 \\
Leverage & $(1.35)$ & $(1.46)$ & $(1.48)$ \\
& -0.333 & -0.324 & -0.312 \\
Firm size & $(-1.17)$ & $(-1.13)$ & $(-1.09)$ \\
& $0.123^{*}$ & $0.130^{*}$ & $0.136^{*}$ \\
Intercept & $(1.71)$ & $(1.81)$ & $(1.89)$ \\
& $-2.239^{*}$ & $-2.422^{*}$ & $-2.579^{*}$ \\
Industry indicator & $(-1.78)$ & $(-1.70)$ & $(-1.82)$ \\
Year indicator & Yes & Yes & Yes \\
\hline $\mathrm{N}$ & Yes & Yes & Yes \\
Adjusted $R^{2}$ & 265 & 265 & 265 \\
\hline
\end{tabular}




\section{Table 7}

\section{Effects of Institutions on the association between political participation and accounting performance}

This table presents the OLS regression results of the effects of political participation and local institutions on changes in accounting performance after the IPO event. The dependent variables in this table are alternatively measured as growth in sales, growth in earnings and ROS change. The independent variables include: Political participation, which equals one if the controlling entrepreneur has political participation before the IPO and zero otherwise; Institutions, the proxy for local institutions; Political participation*Institutions, the interaction of political connections and institutions; Ownership, measured as the percentage ownership of the largest owner; Tobin's $\mathrm{Q}$, measured as the sum of total market valuation of equities and total net liabilities divided by total assets; Leverage, measured as the ratio of total liabilities over total sales; Firm size, measured as natural logarithm of total sales in the IPO year. Industry and year dummies are included but not reported. All variables are winsorized at $5 \%$ and $95 \%$. Robust $t$-statistics are given in parentheses. ***, **, and * denote significance at the $1 \%, 5 \%$ and $10 \%$ level, respectively.

Proxies for institutions are: GDP per capita, measured as above or below the sample median value of local average real GDP per capita during 1979-2007 (Institutions equal one if local GDP per capita is below the sample median value and zero otherwise); Marketization, based on whether or not the firm's headquarter is located in a relatively more developed region, using the National Economic Research Institute (NERI) Index of Marketization for China's provinces (Institutions equal one if a firm's headquarter is located in a less well developed region and zero otherwise); Leased provinces, based on whether or not the firm's headquarter are located in a province that was once leased to industrial countries before 1949 (Institutions equal one if a firm's headquarter is located in a province that was never leased to foreign powers countries before 1949 and zero otherwise). 
Table 7 (Continued)

Effects of political participation and local institutions on accounting performance

\begin{tabular}{|c|c|c|c|c|c|c|c|c|c|}
\hline \multirow{2}{*}{$\begin{array}{l}\text { Institutional proxy } \\
\text { Performance } \\
\text { measure }\end{array}$} & \multicolumn{3}{|c|}{ GDP per capita } & \multicolumn{3}{|c|}{ Marketization } & \multicolumn{3}{|c|}{ Leased provinces } \\
\hline & $\begin{array}{l}\text { Growth } \\
\text { in sales }\end{array}$ & $\begin{array}{l}\text { Growth } \\
\text { in } \\
\text { earnings }\end{array}$ & $\begin{array}{l}\text { Change } \\
\text { in ROS }\end{array}$ & $\begin{array}{l}\text { Growth } \\
\text { in sales }\end{array}$ & $\begin{array}{c}\text { Growth } \\
\text { in earnings }\end{array}$ & $\begin{array}{l}\text { Change } \\
\text { in ROS }\end{array}$ & $\begin{array}{l}\text { Growth } \\
\text { in sales }\end{array}$ & $\begin{array}{c}\text { Growth } \\
\text { in earnings }\end{array}$ & $\begin{array}{l}\text { Change } \\
\text { in ROS }\end{array}$ \\
\hline $\begin{array}{l}\text { Political } \\
\text { participation }\end{array}$ & $\begin{array}{c}0.152^{* *} \\
(2.08)\end{array}$ & $\begin{array}{l}0.360^{*} \\
(1.71)\end{array}$ & $\begin{array}{l}0.011 \\
(0.81)\end{array}$ & $\begin{array}{c}0.096^{* *} \\
(2.24)\end{array}$ & $\begin{array}{l}0.328 \\
(1.59)\end{array}$ & $\begin{array}{c}0.002 \\
(0.40)\end{array}$ & $\begin{array}{c}0.136 * * \\
(2.08)\end{array}$ & $\begin{array}{c}0.323^{*} \\
(1.69)\end{array}$ & $\begin{array}{l}0.011 \\
(0.87)\end{array}$ \\
\hline Institutions & $\begin{array}{l}-0.091 \\
(-1.30)\end{array}$ & $\begin{array}{c}-0.352^{* *} \\
(-1.94)\end{array}$ & $\begin{array}{l}-0.001 \\
(-0.06)\end{array}$ & $\begin{array}{l}-0.089 \\
(-1.02)\end{array}$ & $\begin{array}{c}-0.380 * \\
(-1.71)\end{array}$ & $\begin{array}{c}-0.028^{* *} \\
(-2.43)\end{array}$ & $\begin{array}{l}-0.102 \\
(-1.47)\end{array}$ & $\begin{array}{c}-0.396 * * \\
(-2.23)\end{array}$ & $\begin{array}{l}-0.001 \\
(-0.13)\end{array}$ \\
\hline $\begin{array}{l}\text { Political } \\
\text { participation* } \\
\text { Institutions }\end{array}$ & $\begin{array}{c}-0.159 \\
(-1.19)\end{array}$ & $\begin{array}{l}0.285^{*} \\
(1.69)\end{array}$ & $\begin{array}{c}0.006^{* * *} \\
(2.14)\end{array}$ & $\begin{array}{c}0.136 * \\
(1.78)\end{array}$ & $\begin{array}{c}0.713^{* * *} \\
(2.79)\end{array}$ & $\begin{array}{c}0.035^{*} \\
(1.70)\end{array}$ & $\begin{array}{c}0.127 * * \\
(2.12)\end{array}$ & $\begin{array}{c}0.331^{*} \\
(1.71)\end{array}$ & $\begin{array}{c}0.008 * * \\
(1.88)\end{array}$ \\
\hline Ownership & $\begin{array}{c}0.091 \\
(0.41)\end{array}$ & $\begin{array}{l}-0.107 \\
(-0.19)\end{array}$ & $\begin{array}{l}-0.030 \\
(-1.00)\end{array}$ & $\begin{array}{c}0.090 \\
(0.40)\end{array}$ & $\begin{array}{l}-0.182 \\
(-0.32)\end{array}$ & $\begin{array}{l}-0.033 \\
(-1.12)\end{array}$ & $\begin{array}{l}0.092 \\
(0.42)\end{array}$ & $\begin{array}{l}-0.098 \\
(-0.17)\end{array}$ & $\begin{array}{l}-0.029 \\
(-1.00)\end{array}$ \\
\hline Leverage & $\begin{array}{c}0.277^{* * * *} \\
(3.60)\end{array}$ & $\begin{array}{c}0.056 \\
(0.29)\end{array}$ & $\begin{array}{c}-0.041 * * * \\
(-3.97)\end{array}$ & $\begin{array}{c}0.259 * * * \\
(3.30)\end{array}$ & $\begin{array}{l}0.069 \\
(0.35)\end{array}$ & $\begin{array}{c}-0.039 * * * \\
(-3.78)\end{array}$ & $\begin{array}{c}0.274^{* * * *} \\
(3.55)\end{array}$ & $\begin{array}{l}0.060 \\
(0.31)\end{array}$ & $\begin{array}{c}-0.041 * * * \\
(-3.98)\end{array}$ \\
\hline Firm size & $\begin{array}{c}0.114 * * * \\
(2.83)\end{array}$ & $\begin{array}{c}0.165 \\
(1.59)\end{array}$ & $\begin{array}{c}0.162^{* * * *} \\
(2.96)\end{array}$ & $\begin{array}{c}0.127 * * * \\
(3.08)\end{array}$ & $\begin{array}{l}0.157 \\
(1.51)\end{array}$ & $\begin{array}{c}0.013 * * \\
(2.53)\end{array}$ & $\begin{array}{c}0.114 * * * \\
(2.82)\end{array}$ & $\begin{array}{l}0.163 \\
(1.58)\end{array}$ & $\begin{array}{c}0.016^{* * *} \\
(2.97)\end{array}$ \\
\hline Tobin’s Q & $\begin{array}{c}0.076^{* * * *} \\
(3.56)\end{array}$ & $\begin{array}{c}0.144^{* * * *} \\
(2.62)\end{array}$ & $\begin{array}{l}0.002 \\
(0.77)\end{array}$ & $\begin{array}{c}0.079 * * * \\
(3.05)\end{array}$ & $\begin{array}{c}0.152^{* * * *} \\
(2.78)\end{array}$ & $\begin{array}{c}0.002 \\
(0.75)\end{array}$ & $\begin{array}{c}0.077 * * * \\
(3.63)\end{array}$ & $\begin{array}{c}0.150^{* * * *} \\
(2.75)\end{array}$ & $\begin{array}{l}0.002 \\
(0.77)\end{array}$ \\
\hline Intercept & $\begin{array}{c}-1.957 * * \\
(-2.40)\end{array}$ & $\begin{array}{l}-3.650 * \\
(-1.74)\end{array}$ & $\begin{array}{c}-0.312 * * * \\
(-2.82)\end{array}$ & $\begin{array}{c}-2.225^{* * *} \\
(-2.69)\end{array}$ & $\begin{array}{c}-3.561 * \\
(-1.69)\end{array}$ & $\begin{array}{c}-0.260 * * \\
(-2.37)\end{array}$ & $\begin{array}{c}-1.942 * * \\
(-2.38)\end{array}$ & $\begin{array}{c}-3.607 * \\
(-1.73)\end{array}$ & $\begin{array}{c}-0.311 * * * \\
(-2.82)\end{array}$ \\
\hline Industry indicator & Yes & Yes & Yes & Yes & Yes & Yes & Yes & Yes & Yes \\
\hline Year indicator & Yes & Yes & Yes & Yes & Yes & Yes & Yes & Yes & Yes \\
\hline $\mathrm{N}$ & 246 & 246 & 246 & 246 & 246 & 246 & 246 & 246 & 246 \\
\hline Adjusted $R^{2}$ & 0.171 & 0.074 & 0.159 & 0.152 & 0.075 & 0.181 & 0.169 & 0.079 & 0.160 \\
\hline
\end{tabular}

